\title{
A Study on Socio- Economic Status of Vadar Community
}

\author{
Mrs. Anita Sambhaji Pisal, \\ Assistant Professor, Bharati Vidyapeeth University, Social Science centre, Pune.
}

\begin{abstract}
Vadar community people are different from the other castes in India. The dressing style, language, marriage system, festivals and other social events are also different then other communities. They have acquired more or less traditions and customs of other communities of different communities in respective States of India. It would not be exaggeration if we say that People from Vadar community are first Engineers as they are considered to be the first people who made weapons from the stone. The Vadar community is known by different names in India such as Mati Vadar, Gadi Vadar, Kala Vadar, Patharvat Vadar, Jati Vadar, Jati, Bhoaj etc.

The economic condition of Vadar community is very poor in the Pune District it is observed that they are not able to full fill their basic needs such as food, clothing and shelter. These people are migrated all over country to full fill their basic needs. Most of the rural based people migrate near by the village where they get opportunity of employment.
\end{abstract}

\section{Introduction}

Vadar community is one of the many Indian nomadic communities, known for their hard laborious work though they are found all over India. They are mainly concentrated in Andhra Pradesh, Maharashtra and Karnataka. The estimated population o f Vadar community in Maharashtra was 4.35 Lakhs in 1991. [Source Dr. BARTI Report, Pune, 1991]

The Vadar community is known by different names in India such as Mati Vadar, Gadi Vadar, Kala Vadar, Patharvat Vadar, Jati Vadar, Jati, etc. The main occupation of the Vadar community is traditional work which includes stone cutting, mine work, stone engraver, digging, housing construction ect, They are found working in agriculture laobur and non- agriculture labour in rural part of the Maharashtra state. Very few people are working in urban areas either in Govt. services or Private organizations. There are popular for their hard work in unorganized sector.

Economic condition of Vadar community is very poor; it is observed that they are not able to full fill their basic needs such as food, clothing and shelter. These people are migrated all over country to full fill their basic needs .most of the rural based people migrates near by the village where they get opportunity of employment .

Vadar community people invented many stone apparatus which can be used in our daily life but today this type work is not require to the present society The traditional work is decreasing day by day due to modern technology, atomization and globalization. The use of traditional stone apparatus taken place by new electrical equipments which leading to increase in unemployment of this community.

The main occupation of this community was mining, construction and others are taken place by JCB machine, builders, contractors and labour unions. This also another cause of poverty and unemployment of Vadar community.

\section{Introduction}

\section{Research Methodology}

The present study was conducted in Pune District of Maharashtra state. The study is purely based on primary data collection; the data collection has made from Vadar communities of Pune district. The researcher has been selected 15 villages from 15 Blocks of Pune district to conduct the present study of Vadar community.

To strengthen the database, secondary data has been collected from various books, reports, and record available with government. The present study is supported by various articles and data available on internet articles and experts opinion.

\section{Social Research}

The objective of social research is clearly the discovery of causal relationship in human behaviors. It is generally acknowledged that in human behaviors as much as in natural phenomenon, a large degree of measurable and predictable sets of associations occur. Social Science Research is an organized and scientific effort to acquire former knowledge about the social phenomenon and the social facts. Social Research studies the social values, beliefs, traditions and events. Social Research is the two side of a same coin, which means that theory and practice must go hand in hand. Social research plays a vital role in the field of social sciences. It has 
become an integral part of social work. It is the pursuit of the human with the help of study, observation, comparison and experiment.

In short, the search of knowledge through objectives and systematic method of finding solution to a problem in research. Social Research is related to social life. It investigates and verifies social issues and social interactions. It formulates laws in regard to different social phenomenon and the principles to guide this phenomenon. It also tries to investigate the relationships that exist between various facts and phenomenon of social life.

\section{Social work Research}

Social Work Research is the application of research methods to the production of knowledge that social workers need to solve problems they confront in the practice of social work. The knowledge is useful in appraising the effectiveness of methods and techniques of social work. It provides information that can be taken into consideration by social worker prior to making decisions that affect their clients, programmes or agencies such as use of alternative intervention techniques or change or modification of the programmed.

Social work Research offers an opportunity for all social workers to make differences in their practice. There is no doubt about the face that social worker will be more effective practitioner guided by the findings of social work research.

Social Work Research is regarded as the systematic use of research concepts, methods, techniques and strategies to provide information related to the objectives of social work programmes and practices. Thus, the units of analysis of social work research could be individuals, group, families or programmes of the agency. Social Work Research is the search of knowledge including knowledge of alternative practice and intervention techniques, which would be of direct use of the social work profession and thus enhance the practice of social work methods.

\section{Definition:}

Dr. D.K. Laldas, "Social work Research may be defined as systematic investigation into the problems in the field of social work."

Prof. P. Ramchandran, "Social Work Research is the use of scientific method in the search of knowledge of alternative practice and intervention techniques which would be of direct use to the social work profession."

Social Work Research primarily deals with problems faced by professional social workers, social work agencies and community in their concern with social work functions. In other words, in social work research, the problems to be investigated are always found in the course of doing social work or planning to do it.

It is very obvious that in social work research, the study of problems is done from the point of view of social work and that of professional social work. Social Work researcher lays special emphasis on evaluation. This is the one of the reasons that social work research is also understood as evaluative research.

\section{Selection of the topic}

The present research study is an attempt to examine and describe the socio-economic status, family skills, health status, and educational status Vadar community.

The status of Vadar community in general is not good there for the people of community facing social, economic, health and educational problems not only Maharashtra state but also in other part of India.

A large number of research studies conducted so for on the various denotified communities but known has found conducted research study on Vadar community specially Pune district of ,Maharashtra state , therefore researcher has selected the Pune district of Maharashtra state to explore and describe the problems of Vadar community.

\section{Purpose of the Study}

Vadar Community is scattered in all over the India. This caste is included in the Nomadic Tribes list of Maharashtra state and some other state Vadar community treated as SC/ST. Even though it is considered as backward community and provided services and various schemes by the Govt. but still there is no progress found in this community. The main purpose to selected this topic of present study is to know the basic problems such as superstition, education, health, globalization and occupational changes ,unawareness about the Govt. schemes and Migration of this community. To know and overcome the issues of Vadar community researcher has selected the home district -Pune for the present study . 
Objectives of the Study

1. To Study the socio- economic and educational status of Vadar community

2. To study impact of modernization on Vadar community

3. To study and describe the status of women in Vadar community

4. To study Government schemes and programmers related to Vadar community.

\section{Hypotheses}

The related of unemployment is increased due to impact of globalization /modernization on traditional occupation of Vadar Community.

$>$ Unawareness of Govt. Schemes and Programmes leaded to non development of Vadar community.

\section{Scope of the Study}

The study on the Vadar community was extended to cover the personal interview, family background, socio- economic condition, traditional occupation, education, wages, and health. Further the study was focused on the scope for Vadar community in Pune district. This study can be helpful in the larger level for the development of status of Vadar community.

\section{Universe of the Study}

It consist 15 Blocks were more or less peoples of the Vadar community located in rural and few were in urban areas. The population of the Vadar community in Pune District is seven lakh sixty five thousand. The researcher has selected on villages were the maximum Vadar community located in 15Blocks of Pune District.

\section{Sampling Size}

A total 522 respondents were selected randomly from 15villages in Pune District. Quantitative and qualitative data were generated through personal interview schedule a long with participatory observation, interaction and discussion with key information, aged persons, and housewives and traditional healer.

Table.No-2.1

Sample size of the Vadar Community in Pune district

\begin{tabular}{|r|l|l|l|l|l|l|}
\hline Sr.No & Talukas & $\begin{array}{l}\text { Vadar } \\
\text { Community } \\
\text { Population }\end{array}$ & $\begin{array}{l}\text { No of Families } \\
\text { Vadar } \\
\text { community }\end{array}$ & Villages & $\begin{array}{l}\text { Population of } \\
\text { the Selected } \\
\text { villages }\end{array}$ & $\begin{array}{l}\text { Selected } \\
\text { Sample } \\
5 \%\end{array}$ \\
\hline 1$)$ & Baramati & 65000 & 8000 & Kamblewashwar & 700 & 35 \\
\hline 2$)$ & Daund & $1,00,000$ & 20000 & Daund & 1600 & 80 \\
\hline 3$)$ & Indapur & 35000 & 4000 & Bhandgaon & 600 & 30 \\
\hline 4$)$ & Bhor & 20000 & 1500 & Bhambavde & 300 & 15 \\
\hline 5$)$ & Purandhar & 30000 & 3000 & Purandar & 600 & 30 \\
\hline 6$)$ & Velhe & 10000 & 1000 & Vehle & 300 & 15 \\
\hline 7$)$ & Haveli & 40,000 & 2000 & Haveli & 700 & 35 \\
\hline 8$)$ & Pune city & $1,70,000$ & 42000 & Gokhalenagar & 2100 & 105 \\
\hline 9$)$ & Pimpri & $1,53,000$ & 33000 & Nehrunagar & 1540 & 77 \\
\hline 10$)$ & Khed & 30000 & 3000 & Khed & 200 & 10 \\
\hline 11$)$ & Shirur & 25000 & 2700 & Koregaon & 600 & 30 \\
\hline 12$)$ & Junnar & 20000 & 1500 & Otur & 400 & 20 \\
\hline 13$)$ & Ambegaon & 17000 & 1200 & Kanase & 200 & 10 \\
\hline 14$)$ & Maval & 20000 & 1500 & Hinjawadi & 400 & 20 \\
\hline 15$)$ & Mulshi & 30000 & 3000 & Talegaon & 200 & 10 \\
\hline Total population & $7,65,000$ & 91,900 & Village population & 10,440 & 522 \\
\hline
\end{tabular}


Table.No-2.2

\begin{tabular}{|c|l|l|l|l|}
\hline Sr.No & Talukas & Villages & $\begin{array}{l}\text { Population of the } \\
\text { Selected villages }\end{array}$ & $\begin{array}{c}\text { Selected } \\
\text { Sample } \\
5 \%\end{array}$ \\
\hline 1$)$ & Baramati & Kamblewashwar & 700 & 35 \\
\hline 2$)$ & Daund & Daund & 1600 & 80 \\
\hline 3$)$ & Indapur & Bhandgaon & 600 & 30 \\
\hline 4$)$ & Bhor & Bhambavde & 300 & 15 \\
\hline 5$)$ & Purandhar & Purandar & 600 & 30 \\
\hline 6$)$ & Velhe & Vehle & 300 & 15 \\
\hline 7$)$ & Haveli & Haveli & 700 & 35 \\
\hline 8$)$ & Pune city & Gokhalenagar & 2100 & 105 \\
\hline 9$)$ & Pimpri & Nehrunagar & 1540 & 77 \\
\hline 10$)$ & Khed & Khed & 200 & 10 \\
\hline 11$)$ & Shirur & Koregaon & 600 & 30 \\
\hline 12$)$ & Junnar & Otur & 400 & 20 \\
\hline 13$)$ & Ambegaon & Kanase & 200 & 10 \\
\hline 14$)$ & Maval & Hinjawadi & 400 & 20 \\
\hline 15$)$ & Mulshi & Talegaon & 200 & 10 \\
\hline Total population & Village population & 10,440 & 522 \\
\hline
\end{tabular}

\section{Sources of Data Collection}

The information has been obtained from both primary and secondary sources.

Primary Data: Primary data which include first hand information has been collected by using interview schedule for Vadar Community.

Secondary Data: The secondary but main data was drawn from the Pune district. Maharashtra and other department and also from the personal discussion. Beside this the researcher has used observation method for collection of data.

\section{Tools of Data Collection}

The interview schedule and observation method was used for data collection.

Interview Schedule: The structured interview schedule was prepared in Marathi. For Vadar Community women questions were asked in Marathi and Vadari language which is their mother tongue. The interview schedule covered personal information, family background, traditional working condition and health and health information and other educational and vocational aspects relating to Vadar community.

Observation Method: Observation is a basic method of attaining information about social phenomena under investigation. Researcher has observing the real conditions of women. Mostly these Vadar community economic condition and social background is very poor. Vadar Community was changing her dressing style and life style. Thus all endeavors have been taken to make the study just finding of the study.

Focused Group Discussion: Discussion plays a vital role in the data collection in this study; the researcher discussion with Vadar community collected the relevant information.

\section{Major findings of the study}

- Gender: It is found that $65 \%$ of the respondents were male and $35 \%$ were found to be Female.

- Age: It is found that $41 \%$ of the respondents belonged to the age groups of 46 to 55 years, while $29 \%$ of the respondents were in the age groups of 36 to 45 years, another, $25 \%$ of the respondents were in the age groups of 25 to 35 years and $6 \%$ of the respondents were in the age groups of above 56 .

- Sub caste: It is found that $52 \%$ of the respondents were Gadi Vadar, $34 \%$ of the respondents were Mati Vadar, $9 \%$ were Pathrut Vadar $.5 \%$ of the respondents were Jati Vadar.

- Languages: It is found that $53 \%$ of the respondents were speaking using Marathi language at home $47 \%$ of the respondents were using Telgu language at home.

- Type of family: It is found that $42 \%$ of the respondents belonged to joint family system. $42 \%$ of the respondents were belonged to nuclear family system and only $8 \%$ of the respondents were belonged to single parent family system.

- Accommodation status: $71.3 \%$ respondents having their own houses $.22 .4 \%$ respondents were living in rented houses. $6.3 \%$ respondents were living in relative's houses.

- Education: It is found that $50 \%$ of the respondents who were interviewed were illiterate and $42 \%$ of the respondents were educated up to High School, $3 \%$ of the respondents were Secondary and $5 \%$ of the respondents were having other Degree/Course of education.

- Total stay: It is found that $69 \%$ of the respondents were staying in Pune since 
- 35 years. $17 \%$ of the respondents were staying in Pune district since 50 years. $24 \%$ of the respondents were staying in Pune district since 25 years

- TYPE OF WORK: It is found that, $42 \%$ of the respondents were working in daily wages worker.7 $\%$ of the respondents were working in Driveling sectors. $7 \%$ of the respondents were working in construction work and Stone -mine work. 38\%t of the respondents was working in other types of work.

- Income: It is found that $71 \%$ of the respondents were having a monthly income of Rs. 1000 to $3000.11 \%$ of the respondents were having a monthly income of Rs. 4000 to $6000.7 \%$ of the respondents were having a monthly income of Rs. 7000 to $10000.7 \%$ of the respondents were having a monthly income of Rs. 11000 .to $13000.3 \%$ of the respondents were having a monthly income of Rs. 14000 to 16000 .

- Traditional business: It is found that, $67 \%$ Vadar people were not doing family business and $33 \%$ Vadar people were doing family business.

- Problems faced at work place: It also found that $31 \%$ of the respondents were less employment facing these difficulties in this sector. $30 \%$ of the respondents were working in more time this sector. $7 \%$ of the respondents were pressures in this working sector. $2 \%$ of the respondents were not facing any difficulties in this work sector.

- Supportive business: It is found that $67 \%$ of the respondents were doing supportive business. It is found that, $17 \%$ of the respondent were Selling Domestic Animal (Goat) and Income of supportive Business Per month Rs.500-1000. $19 \%$ of the respondents were selling vegetable and Income of supportive Business per monthRs.1001-1500. $23 \%$ of the respondent were Selling Domestic Animal (Hen) and Income of supportive Business Per month Rs1501-2000. $4 \%$ of the respondents were doing other work and Income of supportive Business per month Rs. Above 2000.

- Hours of work: It is also found that, $41 \%$ of the respondents were working in the 12 hours on her life. $29 \%$ of the respondent were working in the 10 hours on her life. $25 \%$ of the respondent were working in the 8 hours on her life.

- The condition on the job setup: It is also found that, $72 \%$ of the respondents were good condition on the job setup. $18 \%$ of the respondents were better condition of the job setup. $7 \%$ of the respondents were ok condition on the job set up.

- Wife Helping their Husband in their Work: It is also found that, $53 \%$ of the respondents helping their Husband because need of money $19 \%$ of the respondents helping their Husband because Full fill needs of family and working together.

- Condition of Female worker with men worker: It is also found that, $19 \%$ of the respondents were good towards the female workers. $48 \%$ of the respondents were better towards the female workers. 33 percent respondents were ok towards the female workers.

- Customs and tradition: It also found that, $86 \%$ of the respondents were giving the importance to the customs and tradition. $14 \%$ of the respondents were not giving the importance to the customs and tradition.

- Women involve in family decision: It also found that, $43 \%$ of the respondents were woman involve to domestic purpose in decision making in family. Very few recent respondents were involving education and financial purpose.

- Difficulties of Women: It also found that, $32 \%$ of the respondents were woman's facing no freedom to walk in society. $18 \%$ of the respondents were woman's facing social pressure in family. $6 \%$ of the respondents were woman No freedom in job in family.

- Changes: It also found that, $97 \%$ of the respondents were changes in their living Style. $3 \%$ of the respondents were not having changes in their living style.

- It also found that, $30 \%$ of the respondents were changes in our living style in impact of the media. $33 \%$ of the respondents were changes in our living style in impact of the moderations. $13 \%$ of the respondents were changes in our living style in impact of the education

Follow the Rules of society: It is found that, $92 \%$ of the respondents were Following the Rules of society. $8 \%$ of the respondents were not following the rules of the society

- Women facing the society difficulties: It is found that, $43 \%$ of the woman respondents were facing job problem in society. $35 \%$ of the woman respondents were facing no freedom to walk in society. $15 \%$ of the woman respondents were social pressure in society. $4 \%$ of the woman respondents were no freedom in job in society. $3 \%$ of the woman respondents were facing all difficulties in society.

- Education: It is found that, 83 percent of the respondents were going to school. 17 percent of the respondents were not going to school.

- It is also found that, $67 \%$ of the respondents were going to Marathi medium school. $12 \%$ of the respondents were going to English medium school.3 percent respondents were going to Govt. school.

- Economic development: Education is the important instrument of the economic development $81 \%$ of the respondents said that education is the important instrument of the economic development. $19 \%$ of the respondents were not giving answers. 
- Awareness of Government policies: It is found that, $67 \%$ of the respondents were awareness about the government policies. $33 \%$ of the respondents were not aware about government policies.

- Social Development programmes: It also found that, $47 \%$ of the respondents were Organizationing the programmed of the improvement the Vadar community situation. $27 \%$ of the respondents were the awareness programmed of the improvement the Vadar community situation. $22 \%$ of the respondents were the get together programmed of the improvement the Vadar community situation. $5 \%$ of the respondents were the all programmed of the improvement the Vadar community situation.

- Developmental Role of Vadar community: It also found that, $40 \%$ of the respondents were social movement. $34 \%$ of the respondents was arranged the programmed. $15 \%$ of the respondents were help the economic $.11 \%$ of the respondents were all try in community.

- Improvement of the Vadar community: It is found that, $47 \%$ of the respondents were establishing the organization to improve the Vadar community situation. $27 \%$ of the respondents were getting awareness of all types and improve the Vadar community situation. $21 \%$ of the respondents were celebrating get together and discuses the problem in Vadar community.

- Social worker in Vadar community: It is found that $62 \%$ of the respondents told that there were social workers in Vadar community. $38 \%$ of the respondents told that there were not any social workers in Vadar community.

- Government role: It is found that, $82 \%$ of the respondents said that role of the government to improvement the Vadar community status. $18 \%$ of the respondents were not taking proper action to the government to the improvement the Vadar community status.

- Inter-Sub Caste Marriage: It is found that, $31 \%$ of the respondents were not married in Inter-Sub Caste Marriage. $69 \%$ of the respondents were married in Inter-Sub Caste Marriage.

- It is found that, $18 \%$ of the respondents were not allowed inter sub-caste marriage. $11 \%$ of the respondents were Not Value in Society on married in inter sub-caste marriage. Very few percent respondents were not need to married in inter sub- caste marriage

- Marriage celebrated: It is found that, $50 \%$ of the respondents were celebrating in traditional fashion. $31 \%$ of the respondents were celebrating in new fashion. $19 \%$ of the respondents were celebrating both.

- Get dowry: It is found that, $40 \%$ of the respondents were not giving the dowry because following the old system. $20 \%$ of the respondents were giving the dowry because Give the money in bride. $32 \%$ of the respondents was Follow the old system

- Celebrated in festival: It is found that, $41 \%$ of the respondents were celebrating the hanuman jayati. 28 $\%$ of the respondents were celebrating Laximidevi yatra. $13 \%$ of the respondents were celebrating Sidganath yatra .6\%of the respondents were celebrating Masoba Yatra.

- Food Consumption: It is found that, $47 \%$ of the respondents were non-vegetarian. $25 \%$ of the respondents were Vegetarian. $28 \%$ of the respondents were both type of Food Consumption

- It is found that, $37 \%$ of the respondents were non-vegetarian means his like fish. $7 \%$ of the respondents were non-vegetarian means his like meat $.3 \%$ of the respondents were food consumption of other types of meat.

- Addiction: It is found that, $67 \%$ of the respondents were addict habit. $33 \%$ of the respondents were not addicted habit.

- It is found that, $33 \%$ of the respondents were drinker. $25 \%$ of the respondents were Addict in tobacco. $8 \%$ of the respondents were smoking in Cigarette. $2 \%$ of the respondent were smoking Bedi [tobacco].

- Effect on health: It is found that, $43 \%$ of the respondent knew Disability, Ect. $16 \%$ of the respondent knew Chronicle Diseases different illness. $13 \%$ of the respondent knew Seasonal Diseases illness.

- It is found that the $62 \%$ of the respondent were going to thePrimary health care and $21 \%$ of respondents were going to the Govt. hospital, $15 \%$ of respondents were going to priest and very few respondents were going to the private hospital.

- Awareness of the health: It is found that, $72 \%$ of the respondents were aware of the new different illness. $28 \%$ of the respondents were not aware of the new different illness. $43 \%$ of the respondents were not going to the Primary health care and $20 \%$ respondents were going to the Primary health care $.15 \%$ of respondents were not going to the Govt. hospitals, $12 \%$ of respondents were not going to hospitals and 3\% respondents were going to the priest and very few respondents were going to the private hospitals.

- Health camp: It is found that the respondent were $39 \%$ of the Political leader were organizing health camp in your society. $24 \%$ of the Municipal Corporation was organizing health camp in your society. $15 \%$ of the Social N.G.O was organizing health camp in your society. . $21 \%$ of the other people were organizing health camp in your society

- Land ownership: It is found that, $60 \%$ respondents were having land. $40 \%$ of the respondents were not having land. $23 \%$ of the respondents were having land between 1 to 5 acre Bagayat. $11 \%$ of the 
respondents were having land of 5 to 10 acre Girayati. $3 \%$ of the respondents were having land of 10 to 15 acre Padik. 3\%of the respondents were having land of above 15 acres.

- Cropping pattern: It is found that, $3 \%$ of the respondents were taking Javari crops in farm. $6 \%$ of the respondents were taking wheat crops in farm. $2 \%$ of the respondents were taking Millett crop in farm. $4 \%$ of the respondents were taking sugar crop in farm. $2 \%$ of the respondents were taking sun flower crop in farm. $19 \%$ of the respondents were taking rice in fain farm. $3 \%$ of the respondents were taking other type of crops in farm.

- Livestock: It is found that, $13 \%$ of the respondents were having donkeys as livestock. $19 \%$ of the respondents were having bedfellows as livestock's and $12 \%$ of the respondents were not having any live stock. $20 \%$ of the respondents were goat's livestock. $13 \%$ of the respondents was having hen livestock and $11 \%$ of the respondents were Pig live stock. $13 \%$ of the respondents were having other livestock.

\section{Conclusion}

- Vadar community peoples were mostly illiterate and the level of education amongst the literate parents was to secondary school education only.

- Vadar community peoples were carrying good opinion about the attitude of working Vadar woman.

- Vadar community was expert in building structure for Vadar management in the ancient time they built wells ponds, dames, canals for storage \& big bungalows supply of weaker but today's Lack of the traditional work. There for finish the identity of the Vadar community.

- The peoples of Vadar community were not well aware about their health. Because of lack of awareness about health issues, they were not able to prevent diseases.

- The peoples of Vadar community spend their money to celebrate the religious festivals whether they have to take money on loan.

- The impact of the modernization on the religion, customs and traditional work of the Vadar Community.

- Major impact of the Vadar Community population facing in the shape of loss of identity through the establishment of industries that brings in development in the technology and its concurrent side -effects.

\section{Suggestions:}

- Necessary Health, Education and Employment facilities are to be created by Government by early making funds by long-term planning.

- The vocational training should provide long term \& short-term courses to develop skills \& knowledge in Vadar community people.

- Special attention needs to should be given to the Vadar community women and children.

- Important role of the government is to improve the stats Vadar community.

- Government should have a long-term plan for improvement of the Socio-economic status of the Vadar community.

- Awareness amongst the Vadar community women needs to be created by Government for improvement of their status.

\section{Bibliography}

[1]. Myth and identity: the narrative construction of self in the oral tradition of Vadar communities Copyright (C) 2001, Indian Folklore Research Journal, Volume One, Number One, May 2001Guy Poitev in Centre for Co-op. Research in Social Science, Rair Kar Bungalow,884, Deccan Gymkhana, Pune - 411 004, Maharashtra, India

[2]. Joshua Project, Vaddar, Hindu in all countries. 2002. (C) India Missions Association - Edited by Philipose Vaidyar. Joshua Project, View Vadar, Hindu in all countries, PO Box 62614, Colorado Springs, CO 80962-2614, United States, www.joshuaproject.net

[3]. Thade Commission Report in 1999: Government of Maharashtra, Social Welfare Board

[4]. Edate: 1991 Report, Government of Maharashtra, Social Welfare Board

[5]. Motiraj Rathod: Denotified and Nomadic Tribes in Maharashtra'

[6]. The Denotified and nomadic tribes ,Rights action group newsletter ,-June and July-September, 2000 ,Published by DNT Rights Action Group ,6 United venue, Near Dinesh Mills ,Vadodara, India 390007 ,bhasha@bnpl.net

[7]. Social originations in an Indian slum: Dr. Ratan .A. Rao ,First edition-1990, Published by .K.M. Mittal,For Mittal Publication, A1/8, Mohan Garden, New Delhi-110015 